UDC 81'42:811.111(045)

DOI https://doi.org/10.52726/as.humanities/2021.3.25

\title{
V. O. YABLOCHNIKOVA
}

Assistant at the Department of Foreign Philology and Translation,

Vinnytsia Institute of Trade and Economics of Kyiv National University of Trade and Economics,

Vinnytsia, Ukraine

E-mail: veronikayablochnikova93@gmail.com

https://orcid.org/0000-0001-5051-6433

\section{STYLISTIC FEATURES OF ADVERTISING TEXTS AND THEIR REPRODUCTION IN TRANSLATION}

The article deals with linguistic and stylistic peculiarities of advertising texts and factors influencing their translation. Different approaches of advertising texts translation and practicability of lexical semantic transformation usage are analyzed. All statements and conclusions are illustrated with English advertising texts, chosen from mass media resources, and the author's variants of their translation.

"Advertising is not an addition to business, but a vital component of our economy" the Americans say. The uniqueness of such a phenomenon as advertising, is in its super-vitality. Even in times of economic crisis, it doesn't only flourish, but also helps those who use its services to survive and follow its recommendations. Advertising is a complex type of human activity. Advertising was introduced unnoticed and gradually became an integral part of our lives. Wherever we go, whatever we do, advertising is always with us. These are posters, stands, shop windows, calendars and booklets. It has forever taken a dominant position on television and radio, in newspapers and magazines, as well as in the Internet.

While translating the advertising text from other languages it is especially important not to lose the hidden meaning of the advertising message, as each state has its own customs, social communications, norms and canons of communication. Advertising should "sound", be rich and extremely short.

Translation of advertising texts is a complex, creative process that requires consideration of many factors. First of all, we must realize that advertising texts should promote the sale of goods, so they should be as convincing as possible and create vivid images in the minds of consumers. The materials of this study can be used in the work of translators, as well as in subsequent studies of advertising texts, problems of their translation, problems of adaptation of advertising texts to the language of translation, and so on.

Key words: translation, advertising, expressiveness, advertising text, stylistics.

Introduction. Nowadays, it is absolutely impossible to imagine any sphere of human activity without such a phenomenon as advertising. Advertising is aimed at attracting public attention to a phenomenon, product or service. The translation of an advertising text, in contrast to the translation of fiction, in which the translator is obliged to convey the artistic and aesthetic benefits of the original, differs slightly in form, linguistic means, as well as a strong communicative orientation. In the process of translating such texts, the translator has to solve both linguistic problems, due to differences in semantic structure and features of two languages in the communication process, and problems of sociolinguistic adaptation of the text.

Analysis of research. Recently, there has been a growing interest in the study of the media. Advertising as the brightest means of mass communication is no exception. Advertising is an extremely multifaceted phenomenon. It is a dynamic form of mass communication and intercultural communication.
Proof of this statement is the interest of researchers - representatives of various sciences are studying this phenomenon (advertising is studied by psychologists, political scientists, marketers, economists, journalists, linguists). Analyzing advertising, each of the sciences uses its own methodology, methods of studying and terminology. Thus, psychologists and sociologists study the problems of changing human behavior and society under the influence of advertising, motives for choosing a particular product or service, the formation of new patterns of behavior and lifestyle, etc. Linguists study the content of materials that convey advertising messages, they analyze verbal and linguistic aspect of communication and the use of means of expression in the creation of advertising text, messages and visual images [Дурицкая 2009].

Presentation of the main material of the research. Among the specific features of advertising texts, researchers identify the following: 
- compactness (ability of the recipient to cover the text at a glance);

- additionality (as a rule, advertising text specifies either graphic or video image);

- signaling (in the text there is a phrase, which expresses the modality of the entire text of the advertisement);

- hierarchy (advertising text may contain information of several degrees of importance);

- evaluation (the text emphasizes the benefits of the advertised product);

- instructiveness (the text of the advertisement indicates the mechanism of action of the recipient) [Грушевська 2002].

Regarding all the assets listed above, we can conclude that the advertising text should be understood as a message about the subject of advertising, communicative and pragmatic purpose of which is to encourage the recipient to buy the product or use a particular service. In their content, advertising texts are specific, pragmatic, convincing, clear and concise in the presentation of information.

Linguistic influence, as the influence of verbal information on the behavior of the recipient, is formed as a result of the interaction of a number of linguistic and non-verbal factors included in the act of communication [Арнольд 1981]. Advertising text is a clear example of the most effective use of language tools for influence. "An important requirement for advertising texts - maximum information, minimum words" [Грушевська 2002]. The pragmatic aspect of the advertising text is directly manifested in its original organization - the choice of lexical and grammatical units, stylistic devices, special syntax, organization of printed material, the use of elements of different sign systems.

All stylistic figures used in advertising texts can be divided into five groups, depending on their structure and purpose. There are: phonetic, graphic, morpheme, lexical and syntactic units.

1. Phonetic stylistic figures - are designed to convey emotional effects and create vivid images with sound combinations. These include: sound imitation, alliteration, assonance, rhyme. Phonetic stylistic devices are very often used in advertising texts, because a good perception of the message by ear is the key to success. Rhyming slogans are generally very easy to remember and can sometimes even be intrusive. For example: $S-S-S-S-S-S-S-S-S-$ money loves silence. - $U-u-u-u-u-u-$ гроші люблять тишу. Sh-sh-sh-sh-sh-sh-sh-opping for fun - Ti-u-и-ш-и-ш-ся пош-ш-ши-иуками $u-u-u-u-щ, a c m я$ у нас. In both contexts, the subtext is a sense of peace and quiet, with which you should make any money transactions and purchases [Арнольд 1981].

Sound imitation is a combination of sounds, the purpose of which is to imitate the sounds of nature, things, people or animals [Арнольд 1981]. This stylistic device is used to attract attention, because the imitation of sounds is easily understood by consumers even without translation and can cause them to associate with the previous use of such products, thus reminding them of the feelings they received from using this product.For example: Mazda: "Zoom-zoom" "Вжж-вж»" imitation of the sounds of the car ready to start.

Alliteration - repetition of the same consonant sounds, especially at the beginning of words to create the melody of the statement [Арнольд 1981]. Assonance is the repetition of vowel sounds, especially in stressed syllables [Арнольд 1981]. Alliteration and assonance can create the effect of euphony (euphony) - "a feeling of ease of perception and comfort when pronouncing" [Арнольд 1981], which is very important for advertising slogans, because they should evoke positive emotions in customers, and euphony can contribute to this. Advertising slogans often use a combination of several phonetic stylistic figures to create a rhyme - the consonance of words to better remember the advertising slogan. For example: Smile Fast Food: "Fast food, fast good." "Стане швидко тобі good, якщзо ти зайдеш в Fast Food".

2. Graphic stylistic figures are a special group that is used mainly for print advertising, as it is transmitted by changing the spelling of words for a specific purpose. The sound image of words may not change, so if the advertising text with such stylistic means is not accompanied by an image (for example, radio advertising), it is possible not to achieve the goal [Гальперин 2003].

Graphic means include a graph - a deliberate violation of the form of a word in order to convey information about a person's origin, social status, education or emotional state.For example: KFC: "Oooooh yeah!" "Oоооо maк!" - lengthening the letters gives the impression of longevity of enjoyment of the taste of food. 
3. Morpheme stylistic means - are used to convey additional information (logical, emotional, expressive) through the use of suffixes or prefixes with a pronounced logical meaning. For example: Mercedes-Benz: "Unlike Any Other" "Не такий $я \kappa$ yci" - the whole slogan can be replaced by the word "different", but it does not contain such an emotional effect as the word "unlike".

4. Lexical stylistic means - the largest group that occurs in advertising texts, because through the lexical means of speech we can convey the informative part of the message and achieve the desired stylistic effect. This group includes many stylistic devices that are used to emotionally intensify the utterance, to enhance its expressiveness. Special attention should be paid to high concentration of epithets, comparisons, hyperbole, metaphors, personifications that help advertisers to present their product in the best way and attract attention to its advantages among other products, emphasizing its characteristics, creating vivid images in the minds of consumers [Бове 1995].

The translation of an advertising text, compared to the translation of fiction, in which the translator is obliged to convey the artistic and aesthetic merits of the original, differs slightly in form, language, as well as by a pronounced communicative orientation. In the process of translating such texts, the translator has to solve both linguistic problems due to differences in the semantic structure and features of the use of two languages in the communication process, and problems of sociolinguistic adaptation of the text. The translator often has to look for special means to convey the semantic and stylistic components of the original. In this case, a pragmatic equivalence is achieved between the original and the translation, which determines the communicative effect of advertising. The researcher of the creative process of translation A. Lilova considers the translation of advertising texts as "creativity at the language level", while the translation of literary texts - as "creativity associated with artistic thinking" [Бове 1995].

The expresing of the pragmatic potential of the original can be a significant obstacle for the successful translation of advertising. In particular, it is connected with the translation of facts and events in the advertising text which are related to the way of thinking of a certain people through the specifics of their language, its eth- ical and psychological foundations, their national culture, superstitions, customs, etc. Therefore, advertising text should not be translated verbatim, otherwise it may lose meaning and influence or can be interpreted in a distorted way. A characteristic feature of effective advertising is the harmonious combination of the main advertising idea with the means of expression that best reflect such an idea. It is not so easy to find the only correct tone of the advertising appeal, which distinguishes it from others and ensures its success. The translation of advertising, as well as the translation of a literary text, operates with well-known stylistic means, but their combinations, like notes in music, give an unpredictable effect. When translating, not the language message itself is transmitted, but the subtext, the extralinguistic reality embedded in it. Combinations of linguistic tools can also serve as a tool of manipulative influence [Бове 1995].

We can figure out the following means of translation of advertising texts: lack of translation, direct translation, adaptation, revision. In order to outline the feasibility of using each of these tools, let's study them more detaily. It is possible to use the lack of translation when the advertising text has a simple structure and is understandable to a wide range of consumers. These types of advertising texts are used to draw consumers' attention to the foreign origin of the product, and therefore to its better quality. In this case, the trademark name often plays a key role here, and the text of the message is no longer so important, so it does not need translation. Many advertising texts can be translated verbatim. This is facilitated by their conciseness, simple structure and the presence of wellknown words [Бове 1995].

An adaptation technique is used in order to preserve the functionality of the advertising message, This is due to the fact that in English simple phrases can have a deep meaning, which is lost in direct translation. Thus, the translator needs to look for specific means to convey the semantic and stylistic components of the original text, to adapt it to the peculiarities of the language of translation [Гальперин 2003].

Lexical-semantic transformations are used in the translation process if there is a non-standard unit of language in the source text at the level of a word, phrase or phrase. These lexical units play a very important role in the translation process, because, 
being relatively independent of the context, they nevertheless give the translated text a different orientation, depending on the equivalents selected by the translator in the language of translation.

L. Naumenko and A. Gordeeva distinguish the following types of lexical-semantic transformations: choice of variable equivalent, contextual replacement, tracing, descriptive translation, transcoding, antonym translation, compression, decompression, permutation (permutation of words), transposition (nominalization, concretization) meaning, generalization of meaning [Арнольд 1981].

In the process of translating of advertising texts of this type it is very difficult, and sometimes even impossible to maintain equivalence and preserve their effect, so the translator has to choose: either completely change the text of the message and preserve the stylistic effect, or lose it in literal translation. Both options are very risky, because the combination of the content of advertising text and stylistic means allows you to maximize the impact on the consumer. But still, if the whole text of the advertising is built on this technique, and it carries a certain stylistic load, it makes sense to convey this feature. If the transmission of "sound to sound" is not possible, instead you can use the unusual rhythm, word order, rhymes and repetitions [Дурицкая 2009].

Such a phenomenon as the rhyme should also be mentioned. If the entire text is based on rhyme, the translator faces the problem of how to translate such text. In any case, losses are inevitable. The ideal way to translate rhyming text is to create new rhyming text while retaining meaning and style.

Sometimes it is not possible to find a similar equivalent in another language system and the trans- lator has to use different transformations. Among the lexical transformations that are often found in the translation of lexical stylistic means, there are differentiation and concretization; generalization of values; semantic (or logical) development; holistic transformation; compensation. Often the translator uses the techniques of semantic development and holistic transformation as the most creative of all types of transformations, which allows to preserve the function of the image of a foreign language in translation [Дурицкая 2009].

One of the most difficult cases of translating stylistic means of expression is a play on words, and here, as a rule, there is a lot of losses. That is why the translator should first of all ask himself the question: what to sacrifice? To convey the content by omitting the play on words, or to keep the pun by replacing the image, deviating from the exact meaning, even focusing only on the game, completely abstracting from the content?

Conclusions. To crown it all, the translation of advertising texts into other languages is often problematic, because it is not always possible to achieve an equivalent translation. The translation of English-language advertising texts differs in form, language means, and also has a strong communicative orientation. In the process of translating such texts, the translator has to solve various linguistic problems due to differences in semantic structure and peculiarities of the use of two languages.

The prospects for further research. One of the problems that needs to be solved during translation is the study of linguistic and stylistic differences between the Ukrainian and English languages. Taking into account these features and selecting appropriate translation techniques is the key to a good translation.

\section{ЛІТЕРАТУРА}

1. Дурицкая Н. К. Лексические особенности англоязычных рекламных текстов. Вестник Чувашского универcumema. 2009. №1. С. 222-226.

2. Грушевська Ю. Лінгвістичні та психологічні аспекти рекламного тексту. Наукові записки Кіровоградського державного педагогічного ун-ту ім. В. Винниченка. Сер. Філологічні науки (мовознавство). Кіровоград, 2002. Вип. 44. С. 126-131.

3. Арнольд И. В. Стилистика английского языка Москва, 1981. С. 295.

4. Бове К. Л. Современная реклама. Творчество в составлении рекламных текстов. Москва.1995. С. 704.

5. Гальперин И. Р. Перевод и стилистика. Теория и методика учебного перевода. Москва. 2003. С. 416.

\section{REFERENCES}

1. Durytskaya N. K. (2009). Leksycheskye osobennosty anhloyazychnykh reklamnykh tekstov. [Lexical features of English-language advertising texts]. Bulletin of the Chuvash University, no. 1, pp. 222-226.

2. Hrushevs'ka Y.U. (2002). Linhvistychni ta psykholohichni aspekty reklamnoho tekstu. [Linguistic and psychological aspects of advertising texts]. Scientific notes of Kirovohrad State Pedagogical University, no. 44. pp. 126-131. 
3. Arnol'd Y.V. (1981). Stylystyka anhlyyskoho yazyka. [Stylistics of the English language]. Moskow. (in Russian).

4. Bove K.L. (1995). Sovremennaya reklama. [Creativity in composing advertising texts]. Moskow. (in Russian).

5. Hal'peryn Y. R. (2003) Perevod y stylystyka. [Theory and methods of educational translation]. Moskow. (in Russian).

\section{В. О. ЯБЛОЧНІКОВА}

асистент кафедри іноземної філології та перекладу, Вінницький торговельно-економічний інститут Киїського начіонального торговельно-економічного університету, м. Вінниия, Україна

Електронна пошта: veronikayablochnikova93@gmail.com

orcid.org/0000-0001-5051-6433

\section{СТИЛІСТИЧНІ ОСОБЛИВОСТІ РЕКЛАМНИХ ТЕКСТІВ ТА ЇХ ВІДТВОРЕННЯ У ПЕРЕКЛАДІ}

У статті розглянуто лінгвостилістичні особливості рекламних текстів та фактори, які впливають на їх переклад. Проаналізовано різні засоби перекладу рекламних текстів та доцільність використання лексикосемантичних трансформацій. Всі наведені твердження ілюструються прикладами англомовних рекламних текстів, виокремлених із засобів масової інформації, та авторськими варіантами їх перекладу.

«Реклама - це не приправа до бізнесу, а життєво-важливий складник нашої економіки», - говорять американці. Унікальність такого явища, як реклама, в ії зверхживучості. Навіть у періоди економічних криз вона не тільки процвітає, але і допомагає вижити тим, хто користується її послугами і слідує іï рекомендаціям. Реклама - це складний вид людської діяльності. Вироблена в ії результаті продукція сформована таким чином, щоб виявляти вплив на підсвідомість людини. Реклама впровадилася непомітно і поступово стала невіддільною частиною нашого життя. Куди б ми не йшли, що б ми не робили, реклама постійно 3 нами. Це плакати, стенди, афіші, вітрини, календарі і буклети. Панівне місце вона назавжди зайняла на телебаченні і радіо, в газетах і журналах, а також в мережі Інтернет.

Дуже важливо під час перекладу рекламного тексту з інших мов не втратити прихований сенс рекламного повідомлення, оскільки для кожної держави притаманні свої звичаї, соціальні комунікації, норми і канони спілкування. Реклама повинна «звучати», бути насиченою і гранично короткою.

Переклад рекламних текстів - це складний, творчий процес, який потребує врахування багатьох факторів. Насамперед треба усвідомлювати, що рекламні тексти повинні сприяти продажу товару, отже, вони повинні бути максимально переконливими та створювати яскраві образи в думках споживачів. Необхідність аналізу лінгвостилістичних особливостей нових рекламних текстів буде виникати і надалі. Матеріали цього дослідження можуть бути використані у роботі перекладачів, а також у наступних дослідженнях рекламних текстів, проблем їх перекладу, проблем адаптації рекламних текстів до мови перекладу тощо.

Ключові слова: переклад, реклама, експресивність, рекламний текст, стилістика. 